\title{
ON THE POETRY OF RUTH STONE: SELECTIONS AND COMMENTARY
}

\section{Harvey Gross}

In those remote times called the Fifties (the rhetoric of our on-going Cultural Revolution has speeded up the historical process so that events more than five years in the past seem to have occurred in the Pleistocene Era) literary critics speculated on The Death of the Novel. It now seems the critics went into premature mourning; the genre, while suffering some loss in vigor, is alive and well. Not that genres don't grow senile. Lyric poetry in the eighteenth century, modern tragedy and epic, the piano sonata after Beethoven: all suffered an exhaustion of their conventions and a debilitating loss of stylistic coherence. Of course, resurrection may follow entombment; on a Third Day or in a New Era what once no longer seemed possible may emerge structurally transformed and spiritually transfigured.

I propose, then, The Death of Poetry. This observation is purely voluntaristic and probably based on insufficient evidence. I should rather say $A$ Death of Poetry: after the end we doubtless will have a new beginning. Our apocalypse (in the marvelous term of Frank Kermode) will be "disconfirmed" and the world of poetry will go on. But what I currently see in the journals and hear on the poetry-reading circuits testifies to the moribund condition of the art. The most distressing feature is that poetry-at least the kind now possessing normative status-has simply become another phenomenon of the media. Subject matter, technique, the style of oral delivery: all exhibit a depressing uniformity paralleled by "sitcom" on television, by happenings on the political Left, and by other heavings and groanings on the Masscult scene. Subject matter? We have all the pallid echoers of Sylvia Plath's deadly Schrei and Angst. Technique? A Visiting Poet at the university where I teach tells students that "prosody is shit." Confronted by writers of blank prose, by new imitators of imagism, by tin ears which know nothing of the music locked up in the English language, I agree. For them prosody is indeed shit. Metaphor (usually of the violent kind) and startling images replace rhythm as the ground of poetic being; our current period style is based on the old heresy of the "visual-in-the verbal." 1 We are re-living the various movements of the teens and twenties which insisted that poetry was a spatial art, more akin to sculpture than music. Oral delivery? We have poets who wear funny hats, who dovinn or say prayers to Siddhartha; poets who give us a pennyworth of poems and several poundsworth of their sexual experience, their

1 The heresy is not only alive in poetic practice but in the most fashionable literary theory. Theoreticians still persist in viewing the poem as an object, a "thing-in-space," and not as a structure of meanings unfolding in time. Consequently, our literary theologians have been unable to construct "a phenomenology of rhythm." Perhaps it's just as well. 
(so-called) political opinions, their blackness, their troubles with the Wicked Establishment, et cetera ad nauseam. Indeed, they give us everything but good poems.

This by way of polemical introduction to plead the case of a poet who avoids the journals and circuits, who does not write in the period style, and who is a woman. Ruth Stone is the author of two important books, In an Iridescent Time (1959) and Topography and Other Poems (1971). ${ }^{2}$ Mrs. Stone lives on a farm near Brandon, Vermont and makes only infrequent public appearances. Although she has been widely honored (she has won most of the prizes available to writers) she is not, given her excellence, widely known. Absenting herself from what Louis Simpson calls "po' business," she spends her time doing what those seized by the demon must do: write poems. On the occasions Mrs. Stone reads to audiences, she doesn't try to enhance the style of her verse by exhibiting the style of her life; her readings are neither religious rituals nor agitprop. Well, maintaining such austerities, she hardly pleases the many on the poetry scene who have joined The Tribe of the New Life.

She also works within structural and thematic austerities. Many of her poems are rhymed and metered; all exhibit a concern for craft which flows from intelligent use of traditional techniques and imaginative departure from their restrictions. In an Iridescent Time shows some influences of the fifties: balanced pentameters, ballad stanzas, a few sonnets and near-sonnets, even a villanelle ("To an Ancestor"). The prosodies of Topography are more flexible, less concerned with making specific points of form. Consequently, they achieve a more varied music, a more intensely expressive character. Listen to the opening strophe of "Salt," one of Mrs. Stone's most brilliant efforts:

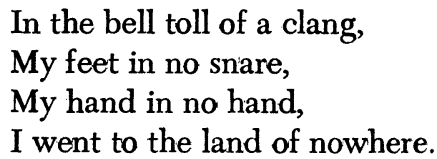

I have no notion of how much Mrs. Stone knows about the medieval lyric and the history of the ballad; however, she knows enough to suit her poetic needs. Here is the second strophe of "Salt":

And it came to pass

The live grass spoke to me,

No woman is fair sang the grass,

They eat up the men, sang the grass

And the mist of the hanging tree

Smiled in the beard of Jehovah,

Pass on said the teeth and tongue,

I mean you no harm,

Take care to be strong,

Admit you are wrong.

2 Both books are published by Harcourt Brace Jovanovich. 
After the formal invitation of the opening, we forget about meters and stanzas (although they continue operating in effective disguises) and enter woman's world.

At this point I will risk the danger of having the Maenads of Women's Lib float my "gory visage down . . . to the Lesbian shore . . ." and insist that Mrs. Stone is a woman poet. Not (God save us) a poetess who publicly cultivates her precious sensibility or who writes Home and Garden verses. As a woman Mrs. Stone writes out of ways of feeling and residues of experience which a man cannot own. A man cannot know how it feels to be a widow, a mother of daughters, or to be imprisoned in that anatomy which is a complex and glorious destiny. No man could have framed the universe of "Salt" with its shuddering evocations of the biblical strictures on womankind and its wicked penetration of the masculine mystique:

You must pay the penalty, they cried, If you insist on being a bride

It's all your fault ...

And all the words of the air

Hissed in my ear,

Share!

Take off your flesh and share, And we'll let you look in

At the sorcerer's virginal house of skin,

Where no woman goes,

For women are nothing but clothes.

And I peeped through the curtain and saw

A houseful of beautiful men.

"Salt" is, of course, more than a sly assessment of sexist attitudes. Mrs. Stone's allegory maintains a discreet distance from ideology and the closest possible contact with experience; she requires no slogans, no activist stance to make her powerful points. Hers is a moral imagination disciplined by personal reality; she makes no pretence to feelings or ideas which issue from outside her own history. The Generation Gap? For Mrs. Stone it is no matter of sociology but the oldest story in the world:

I have three daughters

Like greengage plums,

Sitting all day

And sighing all day

And sucking their thumbs;

Singing, Mama won't you fetch and carry,

And Daddy, won't you let us marry,

Singing, sprinkle snow down on Mama's hair

And lordy, give us our share.

(from Topography) 
All of Mrs. Stone's poetry is richly and genuinely personal, the product of an ego fiercely self-involved yet also capable of wittily devastating or tenderly compassionate outward glances. Her nature is animated by an ironic and entirely original use of pathetic fallacy; in "The Season" everything leaps to physical being through incantatory magic, that is, through language and rhythms which are particular forms of energy:

I know what calls the Devil from the pits,

With a thief's fingers there he slouches and sits;

I've seen him passing on a frenzied mare,

Bitter eyed on her haunches out to stare;

He rides her cruel and he rides her easy.

Come along spring, come along sun, come along field daisy.

Smell the foxy babies, smell the hunting dog;

The shes have whelped, the cocks and hens have lost their wits;

And cry, 'Why,' cry the spring peepers, 'Why,' each little frog.

He rides her cruel and he rides her easy;

Come along spring, come along sun, come along field daisy. (from In an Iridescent Time)

It is Mrs. Stone's fine energy which distinguishes her work from the current style of footless and headless verses or the numerous varieties of ideogrammatic method. (Rhythm, more fundamental than image and possessing equal status with metaphor, gives poetry its basic energies.) Her poetry turns, moves, trembles, with rhythms that are at once expressive and appropriate. "The Season" plays off iambic regularity against "native" strong-stressing; as the lines move toward the refrain (set to a choriambic trot), they fall easily into the older fourbeat music. "Orchard" is composed in sweetly singing tetrameters, revealing how much strength and delicacy reside in traditional metric:

The mare roamed soft about the slope,

Her rump was like a dancing girl's.

Gentle beneath the apple trees

She pulled the grass and shook the flies.

Her forelocks hung in tawny curls;

She had a woman's limpid eyes...

(from In an Iridescent Time)

With only a single metrical substitution (an initial trochee in line three), the music of "Orchard" builds up to an exciting final cadence:

And then the apple trees were new,

And she was new, and we were new,

And in the barns the stallions stamped

And shook the hills with trumpeting. 
All the poem's erotic suggestiveness-a mixture of shyness and longing, shame and desire, terror and resignation-moves toward a nearly perfect climax and resolution of tensions. These lines illustrate what Mrs. Langer means when she speaks of "the morphology of feelings." In "Orchard" the rhythm is an exact articulation of what the propositional sense tells us.

An absolute mastery of rhythmic form holds together the long lines of "The Magnet." The danger of the long line is its tendencies toward diffuseness, toward metrical padding through meaningless extensions of phrases and clauses. But Mrs. Stone handles her lines with the control of a virtuoso; she adjusts the length of her rhythms to the surge and ebb of feeling and to concomitant intensities of language. The poem, strongly but subtly allegorical, sings of “. . my young love/ Thin faced, pointed like a fox ..." who

with the bawdy went crying Up the hounds, through thicket he leaped, through bramble, And crossed the river on rocks.

And there alongside the sheep and among the ewes and lambs, With terrible sleep he cunningly laid his hoax.

(from In an Iridescent Time)

In the last strophe the fox invades the singer's developing consciousness. The lines lengthen almost to the point of metrical breakdown, but then move toward a final, stunning cadence:

Out of the valley and across the river, leaving his sheep's hair, he left the maligned flocks,

I heard him coming through brambles, through narrow forests, I bid my nights unwind,

I bid my days turn back, I broke my windows, I unsealed my locks.

To move from form to substance: there is more genuine erotic feeling inhering in Mrs. Stone's control of rhythm and in her metaphoric strategies than in the current, much celebrated four-letter frankness.

A brilliant example of Mrs. Stone's use of traditional stanzas and meters is "The Measure"; as a "metaphysical lyric" it recalls Blake:

The north wind mourns, the south wind sighs,

The west wind weeps from blinded eyes,

And rolling west, the east wind cries,

All weeping is but vanity.

Let there be light was formed from vision;

Let there be heat, perceived of motion.

God crept with man out of the ocean

And looked upon infinity.

(from Topography) 
A sentient nature weeps with human tears; of course, it is not nature but human feeling that constitutes this poetic reality. I have no information that Mrs. Stone has read Kant, but certainly the last stanza of "The Measure" defines the basic categories of the Kantian epistemology. Not only defines them but incarnates them within poetic structure:

\author{
While transient man's dynamic force \\ From quanta leaps magnetically; \\ Considers God within remorse, \\ Defines the indivisible course, \\ That time and space may be.
}

One of Mrs. Stone's most characteristic and successful generic modes is the Märchen. In an acid comment on what now passes for kid lit, she regrets that the fairy-tale is out of style, that

The dragons, the scale-tailed dragons have gone away,

And the sea serpents no longer play,

Now in the pages we turn

Is the engine that could, the real little stove that

will burn.

("Juveniles" from In an Iridescent Time)

Instead of fairy-tales our children have inherited a cartoon-world where even nature is mechanized: where the road-runner stops in a shriek of brakes and the hawk descends in the noisy terror of a dive-bomber. Mrs. Stone's use of fairy-tale differs from either Randall Jarrell's evocations where Grimm and Belsen are parts of the same smoldering world, or W. S. Merwin's "East of the Sun, West of the Moon" where crystalline imagery and grotesque metaphor carry a discussion of the nature of poetry itself. Mrs. Stone's Märchen issue from the mythologizing of ordinary experience (which then, of course, become extraordinary): growing old and its unwelcome physical changes, the deprivations of poverty and estrangement, the ingratitude of children and friends. Here are some sections from "The Story of the Churn":

I am so rich and poor, cried the widow;

My children are scattered.

When storms come up

And cast the dark shadow,

And tongues of the lightning flicker,

I hide in the root cellar...

Who is this princess stuttering here?

Murmurs the cabbage; by what quorum

Does she cower here out of the storm

When she lives above the stair?

Let us put spiders in her hair ... 
If only the lightning would strike

And suck up the working casks of beer,

Turnips and cabbages, onions and cheeses;

And burn up the quilts, the cribs and laces;

And sweep my fields dry, where the delicate faces

Of all the children in their hiding places

Creep away from now in the fire and shadow.

$\mathrm{Oh}, \mathrm{I}$ am so rich and so poor, cried the widow.

(from Topography)

The conventions of the Märchen include the magical animation of inanimate objects, children hiding in the shadows, the enclosure of magic and Kinderspiele inside the barnyard-the princess and the pig are separated only by nature's nurturing mud. The characters of fairy-tales are poor farm boys and widows, goose girls and Blue, Red, and Yellow Fairies. Class awareness tends to be precise and sharp; Cinderella is one of the downtrodden, her sisters are members of the haute bourgeoisie, and Prince Charming, with true aristocratic disdain for the middle orders, lifts Cinderella out of the ashes. The Märchen also mirrors the child's pain and despair: her dismay with her appearance, the agony of poverty, the awkward changes of adolescence, Oedipal resentment of Momma. In Mrs. Stone's "Swans"

... there was a goose girl quavering in the hedgerow;

An awkward goose girl henned and pecked.

And after a night of dreaming she would wake

To arms like sticks and legs like sticks, sacked

In a hand-me-down ... .

Later, of course, the goose girl turns into a swan, but her character does not improve with her appearance. Her remarkable transformation is scracely noticed; her behavior remains, in the cant term of popular psychology, "immature." She

Hissed at the corners of the house

And at the great maternal bed

Where in connubial hatred lay

Her soul disquieted. ... .

And she was swan upon the glass

And hid her long feet in the water,

And nipped the warm food-giving hands,

And sneered like the proper elder daughter.

(from In an Iridescent Time)

The Märchen can provide a basic myth to sustain a poem's argument. It can also be used allusively as in "Bedtime Story"; in this poem the sudden shift to conscious reflection on a Grimm tale conjures up a memorable vision of horror. Mrs. Stone has been relating the sad story of "Mrs. Hempel and her Katz," one of those daft, witch-like women who scavenge through cities, and her "cat who 
rode her shoulder . . ./ a paper cat, his wafer bones/ Sighed as the wind puffed in his little cage." Mrs. Stone breaks off her narrative (as she tucks the children in for the night), saying:

I'd rather forget them, Kinder, the dead being dead, It's like the babes in the woods, where the leaves so red Covered their dirty faces, and the birds whistled as tears were shed.

(from In an Iridescent Time)

Children give Mrs. Stone endless matter for reflection, worry, despair; and "The world of tots ..." created by In an Iridescent Time becomes in Topography a world of young women. The problems are now different but the concern is still passionate and fierce. The passage of time brings little to clarity; it only complicates the confusions and reminds the poet

Summer is over. In the traces

$$
\ldots \text {. in a loud voice }
$$

Of broken stars it is too late for truces and wars.

You must go down the long stairway

Into the dark coal sack of the sky ...

("End of Summer . . .1969")

These lines are addressed to her three daughters, and ultimately to the whole family; Mrs. Stone generally leaves society to the politicians and focuses the glare of her inquiries on the declining nuclear institution. But the center is gone; Mrs. Stone sings widows' songs, raises her daughters in the puzzlement and grief of a household without a father.

Among the most moving poems in Topography are those evoking the awesome pathos of mutability, disclosing those unwelcome "gifts reserved for age/ To set a crown upon your lifetime's effort." I quote in full "Metamorphosis," certainly one of Mrs. Stone's very best poems:

Now I am old, all I want to do is try;

But when I was young, if it wasn't easy I let it lie,

Learning through my pores instead,

And it did neither of us any good.

For now she is gone who slept away my life,

And I am ignorant who inherited,

Though the head has grown so lively that I laugh,

"Come look, come stomp, come listen to the drum."

I see more now than then; but she who had my eyes

Closed them in happiness, and wrapped the dark

In her arms and stole my life away,

Singing in dreams of what was sure to come. 
I see it perfectly, except the beast

Fumbles and falters, until the others wince.

Everything shimmers and glitters and shakes with unbearable longing,

The dancers who cannot sleep, and the sleepers who cannot dance.

The poem signifies its meanings through rhythm. Although the lines immediately move away from a pentameter base, at the close of each stanza the words fall into full iambic regularity. Only the last line opens out toward a full statement of the singer's predicament: that the past, though dead in the life of The Other, returns in memories and dreams; that the present, though informed with the knowledge gained in hard experience, is helpless through the very facts of its inheritance. The poem divides the singer into two: the older ego, the "I" who struggles more fiercely as "the beast/ Fumbles and falters . . ." and The Other, the spendthrift self who could not properly value her rich physicality, who could not see for happiness, "who slept my life away." The older ego has the vision ("I see it perfectly ...."); The Other, lulled by her intuitive closeness to the world of experience, was, in a provocative sense, asleep in her youth. In that closed sleep of youth, The Other sang "in dreams of what was sure to come." What came was the decay of the physical self and increased liveliness of imagination; as the body began to fall apart, mind and sensibility gradually awoke.

A similar theme is advanced in "Liberation." The poem begins with some ironic ideological sallies on woman's fate. "Secure the man when young and then repent/ Amid his willows and his streams." The Other Self will be unconscious and content with her limited field of experience; the world of dominant males tells her she has "No bloodless sorrow . . .": that is, she can only know the sufferings of the body and not the superior metaphysical agonies-these are the exclusive property of men. The poet replies,

Whose bones attest to this?

We ache, we grow fat, we are oppressed.

Metamorphosis deceives our innocence.

Morning after morning slips

The spider with her web across our lips.

She does not really give the lie to women having "No bloodless sorrow . .." Rather she uses all the resources of her art to universalize the problem; women, men, all of nature succumb to change. Time, the Ugly Magician, transforms us all; even the golden heroes and heroines of the newest ideologies must come to dust. Bloodless sorrow, psychological discomforts, metaphysical yearnings-all are resolved by the total liberation of our common fate.

Mrs. Stone has other moods. "Seat Belt Fastened?" celebrates a precarious but always exciting existence lived close to the natural world. The mythic presence of "Old Bill Pheasant" is emblematic of nature's ability to stimulate the forces of imagination: in Wordsworth's language, to summon that "Awful Power 
... from the mind's abyss ... ." However, there is little Wordsworthian solemnity about Mrs. Stone's world; her forces of imagination are filtered through a completely modern sense of irony.

Old Bill wandered in my waking dream,

A river dream; when I saw him come

I was riding by with my gas tank high

Down to Otter Creek from my just-right home.

And he put his beard in the window and said,

"It's sleazy and greasy but it's in your head.

Tell me woman, do you carry a comb?"

The fantasy begins innocently enough; Old Bill (like the river god Tom Bombadil in Tolkien's The Fellowship of the Ring) makes his appearance with benign and boisterous good humor. But as the rhythm of the poem quickens with the increasing speed of the automobile ride (out of the silent comedies), the poem shifts into a sinister mood. The accelerating four-beat meter-reminiscent of Eliot's Sweeney Agonistes-accentuates the terror of a headlong plunge into the future and the regret for an unredeemed past ("And the good time's coming on yesterday"):

Is your seat belt fastened? Do you sleep in your bed?

If you're stuck in the river can you shift to red?

If you're coming are you going?

If you're living are you dead?

And we drove him away where the otters play,

Where it's twice on Sunday in the regular way,

Where they say what they know and they know what they say,

And the good time's coming on yesterday.

"To live a life is not to cross a field." So runs the last line of Pasternak's "Hamlet." To read Mrs. Stone's two books is to experience the rhythms of a life lived with an extraordinary awareness to every nuance of feeling: to every pain and sorrow. She does not make poetry through the deformation of language or the stringing out of images; every poem is a response and a creation. Consequently, she belongs to no school, espouses none of the restrictions which make so much recent poetry a niggling game of dada images, asyntactical phrasing, unrhythmical periods. The language of her poems, like the language of all good poetry, is thoroughly transparent; we are not stopped by the thickness of an image or the cleverness of a simile from perceiving the what of her poetic discourse. Her basic gift is musicality, an "auditory imagination" capable of rendering even the most usual words evocative of the deepest feeling. Her bending the bow of language, making it tense with association and symbolic resonance, begins with the manipulation of rhythm. The final strophe of "Salt" starts and stops in the meter which the Greeks called The Minor Ionic: 


\author{
In the hourglass \\ It came to pass \\ I returned from where I died, \\ With my funeral veil \\ And my fairy tale \\ And the tears I never cried, \\ And the story's grown stale, \\ Female and Male, \\ Where the stars fly, \\ And we all die \\ On the down side.
}

The faintest hint of a thud, generated by the $U \mathrm{U} / /$ of the meter, is enough to qualify and control the pathos of this narrative. The resulting ironic perspective serves to universalize what otherwise would be Mrs. Stone's very sad and very private story. We are all victims together of time's depredations, unbearable grief and bereavement, our sex, and finally of death. I know of no recent poetry which says any more or says it any better.

\title{
T H E T REE
}

I was a child when you married me, A child I was when I married you.

But I was a regular mid-west child, And you were a Jew.

My mother needled my father cold, My father gambled his weekly gold, And I stayed young in my mind, though old, As your regular children do.

I didn't rah and I hardly raved, I loved my pa while my mother slaved, And it rubbed me raw how she scrimped and saved When I was so new.

Then you took me in with your boney knees, And it wasn't them that I wanted to pleaseIt was Jesus Christ that I had to squeeze; $\mathrm{O}$ glorious you.

Life in the dead sprang up in me, I walked the waves of the salty sea, I wept for my mother in Galilee, My ardent Jew. 